\title{
DAYA JUANG SUKARELAWAN SATGAS COVID-19 DALAM TATANAN KEHIDUPAN BARU
}

\author{
Ifit Novita Sari*, Fellin Juniarsi \\ Fakultas Keguruan dan Ilmu Pendidikan, Universitas Islam Malang \\ *korespondensi email: inovsari@unisma.ac.id
}

\begin{abstract}
ABSTRAK
Masa pandemi karena adanya Covid-19yang sedang melanda dunia, maka salah satu dampak dari adanya pandemi tersebut adalah dengan tidak melakukan kegiatan yang menimbulkan keramaian tanpa pengawasan aparat kesehatan. Di masa pandemi seperti ini seluruh kegiatan 90\% dilaksanakan secara daring baik dari sisi pekerjaan dan sekolah. Namun tidak bagi warga yang bekerja sebagai pedagang, petani dan juga pekebun mereka cenderung melakukan kegiatan dengan melibatkan khalayak ramai. Namun hal itu tidak menyurutkan niat sukarelawan terkait hambatan-hambatan dalam memberikan edukasi kegiatan warga dalam mencari ekonomi selama pandemi, dengan harapan warga tetap menjaga kesehatan dengan mematuhi protokol kesehatan yang dianjurkan oleh pemerintah dengan menjaga jarak mencuci tangan dan menggunakan masker. Kegiatan yang dilaksanakan pada kegiatan ini yakni dengan tetap memberikan edukasi dan arahan kepada masyarakat mengenai pentingnya tetap menjaga jarak, cuci tangan dan menggunakan masker saat melibatkan atau terlibat dengan khalayak ramai selama pandemi.
\end{abstract}

Kata Kunci: sukarelawan; service learning; KSM-T

\section{PENDAHULUAN}

Akhir tahun 2019, Wuhan menghebohkan dunia dengan virus corona atau Covid-19. Virus ini dapat dengan cepat menyebar ke seluruh pelosok dunia, termasuk Indonesia. Penyebaran Covid-19 di Indonesia yang semakin meluas, memaksa pemerintah untuk serius mempertimbangkan kasus tersebut (Rahman \& Satria Utama, 2020). Menurut Badan Kesehatan Dunia (WHO), saat batuk atau bersin, Covid-19 biasanya ditularkan melalui droplet atau percikan air liur orang yang terinfeksi. Selain itu, virus juga menular dengan cara yang sama seperti influenza. Virus tersebut menyerang sistem pernafasan dan dapat menyebabkan kematian akibat penyakit pernafasan (pneumonia akut). Terkait pengobatan, WHO masih mengkoordinasikan upaya pengembangan vaksin dan obat pencegahan dan pengobatan Covid-19 (WHO, 2020).

Covid-19 berdampak besar pada semua aspek kehidupan dunia, terutama mengancam kesehatan manusia. Selama pandemi ini, kesehatan merupakan aspek kehidupan yang sangat penting. Tanpa tubuh yang sehat, kita tidak akan bisa melakukan aktivitas seperti biasa, atau malah menghambat aktivitas. Setiap individu harus menjaga kesehatan untuk melindungi diri sendiri (Martino et al., 2018). Pada keadaan pandemi seperti saat ini, menjaga kebersihan dan kesehatan sangatlah penting. Tubuh tetap harus terjaga dari keadaan sehat jasmani untuk menghindari virus dan penyakit. Mengubah kebiasaan memang sulit, tetapi dalam keadaan pandemi seperti saat ini, kita harus 
menyadarkan diri kita akan pentingnya menjaga perilaku bersih dan sehat. Covid-19 tidak memandang siapa yang dapat terinfeksi virus, tetapi siapa pun dapat tertular virus tersebut. Oleh karena itu, mengubah pola pikir dengan menerapkan pola hidup bersih dan sehat menjadi salah satu upaya pencegahan Covid-19 (Channel News Asia, 2020).

Selama pandemi sikap peduli terhadap pandemi Covid-19 sangat perlu. Adanya pandemi Covid-19 hal ini telah mengubah kebiasaan masyarakat. Setiap orang di setiap keluarga bekerja keras untuk mengatasi atau memutus mata rantai penularan epidemi ini. Kebiasaan masyarakat yang paling menonjol adalah kebiasaan hidup bersih dan sehat (Dhiani et al., 2021). Selama ini hal tersebut sangat jarang atau jarang dilakukan di masyarakat. Namun dengan pandemi saat ini, kebiasaan hidup bersih dan sehat sudah mulai berdampak di masyarakat. Faktanya, setiap orang menjalani gaya hidup bersih dan sehat di rumah dan komunitasnya.

Perilaku hidup bersih dan sehat adalah cara untuk meningkatkan pengetahuan, sikap dan perilaku melalui saluran komunikasi terbuka, memberikan informasi dan memberikan pendidikan untuk membantu orang mengenali dan mengatasi pikirannya sendiri, menciptakan pengalaman belajar bagi individu, keluarga, kelompok dan komunitas atau berkreasi untuk mereka upaya bersyarat (Mardiyani et al., 2020). Permasalahannya sendiri membuat masyarakat sadar, mau dan mampu mempraktikkan kebiasaan hidup bersih dan sehat. Perilaku hidup bersih dan sehat merupakan upaya dari seluruh perilaku hidup bersih dan sehat yang harus diawali dengan kesadaran pribadi agar seluruh anggota keluarga dapat membantu diri sendiri, keluarga dan masyarakat dalam bidang kesehatan dan kebersihan (Saputra et al., n.d.).

Mahasiswa Universitas Islam Malang melaksanaan kegiatan Kandidat Sarjana Mengabdi-Tematik (KSM-T) yang dilaksanakan secara domisili tepatnya di RT, 2 RW. 6, Dusun Kebumen, Desa Mulyasri, Kecamatan Tomoni, Kabupaten Luwu Timur, Sulawesi Selatan. Pelaksanaan KSM-T domisili dilakukan di daerah masing-masing berdasarkan jumlah mahasiswa. Kegiatan KSM-T dilaksanakan hanya setingkat RT agar tidak melebihi kapasitas kerja mahasiswa yang dilaksanakan secara individu. Program yang akan dilaksanakan mahasiswa KSM-T di RT. 2 RW. 6 Dusun Kebumen berupa kegiatan sukarelawan menjadi satgas Covid-19. Kegiatan tersebut menemui beberapa hambatan yang dialami mahasiswa sebagai praktikan, sehingga mahasiswa mengerti masalah apa saja yang ada di masyarakat selama menjalani proses kegiatan KSM-T.

\section{METODE}

Metode pelaksanaan KSM-T di RT. 2 RW. 6 Dusun Kebumen menggunakan metode service learning. Kegiatan awal adalah dengan penuh kerendahan hati, mahasiswa melakukan silaturahmi awal kepada bapak RT dengan memberikan surat izin untuk melakukan kegiatan KSM-T di wilayah KSM-T di RT. 2 RW. 6 Dusun Kebumen. Selanjutnya setelah izin diberikan, mahasiswa melakukan identifikasi dan observasi di RT tersebut sebagai lokasi KSM-T dan menemukan permasalahan yang dihadapi warga di RT tersebut. Kegiatan menemukan masalah di masyarakat merupakan proses belajar (learning) bagi mahasiswa (Bawole \& Oentoro, 2019).

Setelah menemukan masalah yang cukup krusial, maka mahasiswa mulai menyusun rencana kegiatan untuk mejadi sukarelawan Covid-19. Kegiatan yang akan dilakukan berdasarkan dari masalah dan kebutuhan warga di RT tersebut. Pada saat observasi mahasiswa juga menggali data seberapa paham masyarakat di RT. 2 RW. 6 Dusun Kebumen mengetahui adanya pandemi Covid-19. Data tersebut akan digunakan untuk menentukan kagiatan yang akan dilakukan mahasiswa sebagai satgas Covid-19. Seluruh kegiatan 
mahasiswa tetap dalam pantauan dan bimbingan dosen pembimbing lapangan agar kegiatan tetap terlaksana dengan baik tanpa menimbulkan masalah baru di lokasi KSM-T.

Pelaksanaan kegiatan berupa service yang dilakukan mahasiswa sebagai satgas Covid-19 adalah membantu bapak ketua RT. 2 RW. 6 Dusun Kebumen dalam mengedukasi warganya agar tetap waspada dan tidak menganggap remeh pandemi Covid-19. Berinteraksi lebih dekat dengan warga di RT. 2 RW. 6 Dusun Kebumen merupakan cara ampuh untuk memahamkan betapa pentingnya melakukan dan tetap menjaga protokol kesehatan selam berinteraksi dengan warga lainnya dalam menjalankan aktivitas pekerjaannya sehari-hari (Bawole \& Oentoro, 2019).

Berbagai pendekatan berupa himbauan tetap melaksanakan protokol kesehatan dalam setiap aktifitas, dilakukan mahasiswa pada forum yang dilaksanakan desa atau RT tersebut, seperti disaat kegiatan posyandu dan gotong royong rutin, karena bapak kepala desa dan RT setempat selalu mengingatkan mahasiswa untuk tidak melakukan kegiatan yang melibatkan khalayak ramai tanpa pengawasan aparat desa. Mahasiswa juga dibatasi kegiatannya oleh kepala desa setempat, pemberian masker dan hand sanitizer dilakukan dengan mendatangi langsung rumah warga setempat diselingi dengan himbauan untuk tetap menjaga kesehatan selama pandemi (Meihartati, 2020).

Untuk menyiasati ketidakkondusifan di situasi seperti ini, kegiatan pembagian masker dilaksanakan dengan cara mendatangi rumah warga satu persatu. Hal ini dilakukan guna menghindari kegiatan yang mengundang khalayak ramai tanpa pengawasan aparatur desa setempat saat kegiatan berlangsung. Hal ini cukup efektif dan membuat para warga tidak melakukan kegiatan yang menimbulkan kerumunan. Membuat kegiatan dengan penuh kehati-hatian selama pandemi supaya kegiatan tidak rumit dan tidak perlu berdesakan dengan khalayak yang tidak mematuhi aturan protokol kesehatan.

Metode ini sangat cocok diterapkan bagi mahasiswa KSM-T di kawasan zona merah. Dengan menggunakan metode ini warga tidak perlu berdesakan dengan tidak mematuhi protokol kesehatan, menjaga jarak dan menggunakan masker di tempat umum. Sukarelawan hanya perlu menyisihkan waktu untuk tetap menjaga kondisi lingkungan selama pandemi dan rela meluangkan waktu dan tenaga selama mengabdi sebagai relawan kesehatan. Solusi ini diterapkan agar mengurangi penyebaran Covid-19 selama pandemic (Farokhah et al., 2021).

\section{HASIL DAN PEMBAHASAN}

Pandemi virus Corona melanda seluruh dunia, termasuk Indonesia, dan mengubah tatanan kehidupan masyarakat. Setelah perubahan selama pandemi ini, baik organisasi kesehatan maupun pemerintah mengumumkan serangkaian kegiatan. Pemerintah mengatur perilaku masyarakat di seluruh negeri untuk menghentikan kecepatan penularan. Situasinya merupakan kelompok sosial terkecil, misalnya keluarga harus mampu bertahan dan selamat dari pandemi Covid-19. Salah satu rencana yang dilaksanakan pemerintah adalah penerapan gaya hidup sehat. Padahal, anjuran ini sudah digunakan oleh bidang kesehatan jauh sebelum pandemi. Pelaksanaan kegiatan pembagian masker dan hand sanitizer serta penyuluhan tentang pentingnya menjaga kebersihan dan kesehatan selama pandemi, merupakan kegiatan awal KSM-T selama tinggal di RT. 2 RW. 6 Dusun Kebumen.

Pola hidup sehat dapat ditiru dengan memberikan edukasi kepada anggota keluarga yang sudah dewasa sehingga mereka dapat mengembangkan kebiasaan sehat yang baik, terutama pada saat terjadi pandemi. Anggota keluarga kecil atau anak-anak cenderung meniru perilaku orang dewasa di sekitar mereka daripada memberikan instruksi langsung. Orang tua, kakek, nenek, dan orang dewasa keluarga lainnya wajib menerapkan perilaku hidup sehat dengan gaya hidup bersih dan sehat, serta melakukan cara pembersihan yang 
benar pada ruang hidup dan lingkungan sekitarnya secara berkelanjutan (Rahmawati et al., 2021).

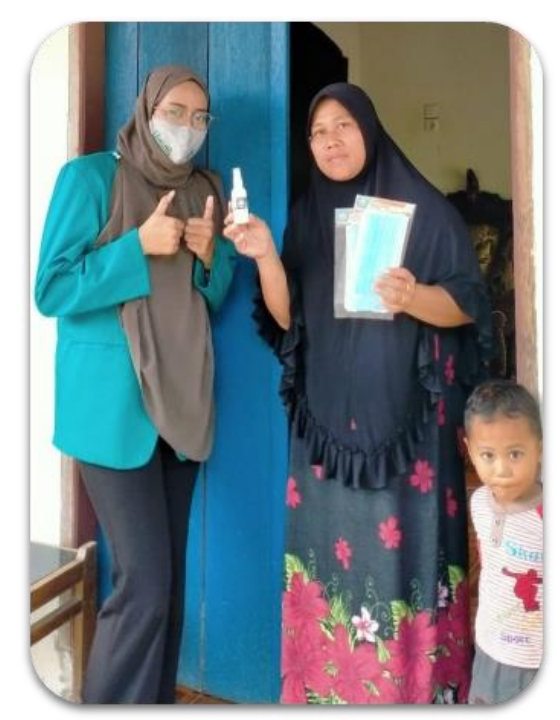

Gambar 1. Pembagian masker ke rumah warga RT. 2 Dusun Kebumen

Sebagai mahasiswa praktikan yang mengabdi di tingkat RT, mahasiswa berharap masyarakat setempat dapat mengarahkan seluruh anggota keluarganya untuk menerapkan pola hidup bersih dan sehat yang menjadi kunci keberhasilan program KSM-T. Semua anggota keluarga bisa saling mengawasi agar anaknya berperilaku bersih dan sehat. Hal terpenting untuk membentuk pola hidup bersih dan sehat adalah lingkungan masyarakat harus memiliki pola perilaku yang sama. Kebiasaan hidup bersih dan sehat dapat dikatakan sebagai upaya penguatan budaya suatu masyarakat atau kelompok sosial pada saat terjadi pandemi dengan mengutamakan kesehatannya, dan dapat terus lebih memperhatikan kualitas hidup (Sumampouw, 2020).

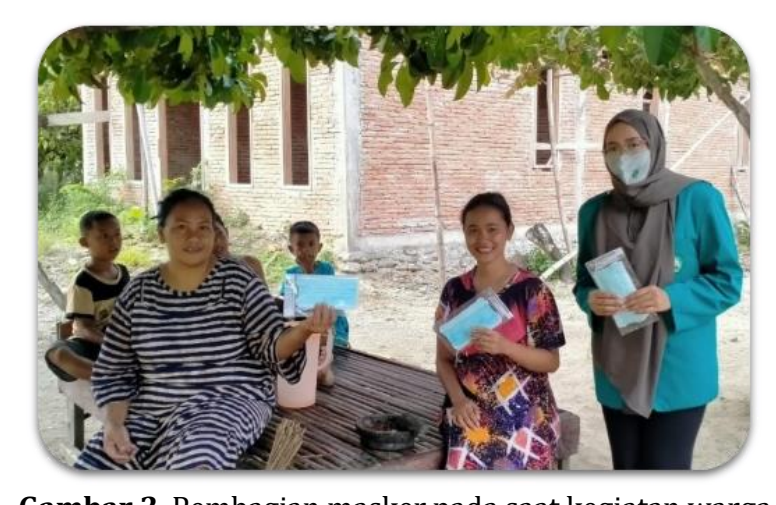

Gambar 2. Pembagian masker pada saat kegiatan warga

Hambatan kegiatan selama pandemi adalah kurangnya kepekaan sebagian penduduk setempat terhadap kesehatan mereka saat berkumpul di depan umum. Ketika melakukan aktivitas di tempat umum, banyak warga sekitar yang masih enggan menggunakan masker karena merasa "sesak dan sulit bernapas". Meski demikian, peserta KSM-T tetap berusaha dan berupaya memberikan pemahaman tentang keberadaan virus pada saat pandemi untuk mencegah dan mengurangi penyebarannya. Harga masker di Torobu masih cukup mahal yakni Rp 150.000 per 50 buah. 
Mahasiswa membagikan 3 masker ke masing-masing rumah. Desa menyediakan dana untuk hand sanitizer, namun botol semprot yang digunakan masih menggunakan dana pribadi mahasiswa KSM-T. Harga tiap botol semprot Rp 2.500 untuk $65 \mathrm{ml}$. Stok masker yang dikumpulkan mahasiswa KSM-T sebanyak 200 buah dan hand sanitizer 30 botol. Pembagian masker dan hand sanitizer masih sangat terbatas, ketiadaan dana mengakibatkan tidak meratanya penyaluran masker dan hand sanitizer ke rumah warga di RT. 2 dusun Kebumen, desa Mulyasri dan masyarakat sekitar di dusun Kebumen, Kecamatan Tomoni.

Masyarakat RT 2 memiliki 70 kepala keluarga (KK), sehingga karena terbatasnya persediaan botol hand sanitizer, mahasiswa KSM-T membagikan masker tanpa hand sanitizer di 40 rumah lainnya. Selain memberikan masker dan hand sanitizer, mahasiswa KSM-T ini juga memberikan beberapa informasi tentang cara agar tetap sehat selama pandemi yaitu olah raga teratur, berjemur, mengkonsumsi vitamin $\mathrm{C}$, membuat ramuan jahe, temu ireng, dan kunyit sebagai minuman seduhan. Minuman rimpang-rimpangan ini berkhasiat meremajakan tubuh sekaligus menjaga daya tahan tubuh. Kegiata lainnya memberikan edukasi tentang mencuci tangan tangan yang baik sesuai anjuran dokter, membersihkan lingkungan selokan dan genangan air yang menyebabkan tumbuhnya jentikjentik nyamuk. Nyamuk juga bisa menimbulkan penyakit. Tidak semua orang bisa melakukannya, hanya sedikit orang yang bisa melakukannya. Warga cukup antusias dan mengikuti arahan menjaga lingkungan sekitar dari faktor patogen.

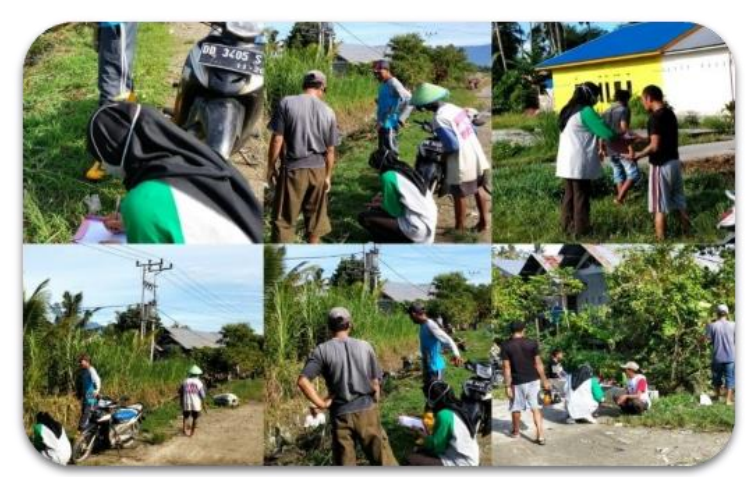

Gambar 3. Keterlibatan mahasiswa KSM-T membersihkan lingkungan warga

Solusi untuk mengurangi masalah-masalah tersebut, dari pihak desa harus membantu memfasilitasi warga dengan rutin memberikan peringatan sekaligus edukasi tentang Covid-19 yang kini masih tetap berkembang. Warga sudah mulai tak begitu memperdulikan lagi seiring menurunnya kepercayaan masyarakat tentang adanya Covid19. Pemberian masker kepada warga dimaksudkan agar warga selalu waspada, ingat dan tetap menjaga kesehatan selama pandemi.

Dengan demikian dapat diperoleh pengalaman selama menjadi sukarelawan satgas Covid-19 di RT. 2 dusun Kebumen pada saat KSM-T. Efeknya bagus, programnya tepat sasaran, dan tercapai. Untuk mengatasi hambatan-hambatan seperti beberapa masyarakat yang tetap tidak menggunakan masker saat melakukan aktivitas di tempat umum mahasiswa tetap memberikan himbauan dan arahan agas tetap menggunakan masker. Oleh karena itu, untuk bisa tetap menjaga kesehatan sesuai protokol kesehatan seperti yang telah diarahkan oleh pemerintah untuk menjaga kesehatan. Perlu adanya sinergi antara aparat dan sosok tokoh masyarakat setempat untuk tetap lapang dada dan luwes dalam memberikan himbauan dan edukasi mengenai bahayanya Covid-19 (Meihartati, 2020).

\section{KESIMPULAN}


Seiring menurunnya kepercayaan masyarakat tentang adanya Covid-19, warga sudah mulai tak begitu memperdulikan lagi protokol kesehatan ketika beraktifitas di luar rumah. Masalah tersebut ditemukan pada lokasi KSM-T di RT. 2 dusun Kebumen. Mahasiswa KSM$\mathrm{T}$ yang melakukan kegiatan pengabdian di wilayah tersebut mengambil inisiatif untuk membagikan masker agar warga selalu waspada, ingat dan tetap mejaga kesehatan selama pandemi. Himbauan untuk tetap menjaga kesehatan dan tetap melaksanakan protokol kesehatan terus didengungkan pada saat ada acara atau kegaiatan rutin yang dilakukan warga. Cara seperti ini cukup efektif karena melibatkan aparat dan tokoh masyarakat yang disegani warga.

Solusi untuk mengurangi masalah-masalah tersebut, dari pihak desa harus membantu memfasilitasi warga dengan rutin memberikan himbauan sekaligus edukasi tentang Covid-19 yang kini masih tetap menjangkiti Indonesia. Metode ini rupanya bisa membuat para warga tidak melakukan kegiatan yang menimbulkan kerumunan. Setiap kegiatan selalu penuh kehati-hatian dan dalam pengawasan aparat berwenang. Harapannya bahwa dalam tatanan kehidupan baru, menjaga kesehatan dan tetap melakukan protokol kesehatan menjadi budaya dalam setiap aktifitas masyarakat terutama jika berkegiatan di luar rumah.

\section{UCAPAN TERIMA KASIH}

Ucapan terima kasih disampaikan setinggi-tingginya kepada Universistas Islam Malang yang telah menyelenggarakan kegiatan KSM-T. Mahasiswa KSM-T selaku sukarelawan satgas Covid-19 di RT. 2 dusun Kebumen juga menyampaikan terima kasih yang sedalam-dalamnya kepada bapak kepala desa Mulyasri dan bapak ketua RT. 2 dusun Kebumen atas ijin yang diberikan, sehingga dapat melakukan kegiatan KSM-T di wilayah kerja desa Mulyasri. Semoga jalinan kerja sama ini dapat ditindaklanjuti dengan program lainnya yang dapat membantu kinerja pemangku kebijakan di desa Mulyasri untuk mensukseskan program pemerintah mewujudkan tatanan kehidupan baru di masa pandemi Covid-19.

\section{DAFTAR RUJUKAN}

Bawole, P., \& Oentoro, K. (2019). Service-Learning sebagai Alternatif Metode Pembelajaran Mahasiswa dalam Pengabdian kepada Masyarakat" Studi Kasus: IFSTS-L Yogyakarta, Halmahera Utara, dan Sumba Tengah". PROSIDING SEMINAR NASIONAL PENDIDIKAN FISIKA" MOTOGPE".

Channel News Asia. (2020). Wuhan virus outbreak: 15 medical workers infected, 1 in critical condition. Channel News Asia.

Dhiani, B. A., Nurjanah, S., Putri, N. I., \& Umam, I. I. (2021). Peningkatan pengetahuan guru dan orang tua siswa taman kanak-kanak tentang penggunaan suplemen vitamin yang tepat. Jurnal Inovasi Hasil Pengabdian Masyarakat (JIPEMAS), 4(2), 161-168. https://doi.org/10.33474/jipemas.v4i2.9138

Farokhah, L., Ubaidillah, Y., \& Yulianti, R. A. (2021). Penyuluhan Disiplin Protokol Kesehatan Covid-19 Di Kelurahan Gandul Kecamatan Cinere Kota Depok. Prosiding Seminar Nasional Pengabdian Masyarakat LPPM UMJ, 1(1).

Mardiyani, S. A., Hidayatullah, M., Sofa, M. Z., Delphia, P., Muhamad, H., Nugraha, M. A. T., Pirain, A. S., Yaqin, M. A., Sukari, S., Bajuber, H. A. A., Mulya, M. B. B., Abbas, T. B., Azrina, S. N., \& Syahputra, V. T. (2020). Edukasi Praktek Cuci Tangan Standar WHO dan Peduli Lingkungan. Jurnal Pembelajaran Pemberdayaan Masyarakat (JP2M), 1(2), 85-91. https://doi.org/10.33474/jp2m.v1i2.6531

Martino, Y. A., Sulistiowati, E., \& Purnomo, Y. (2018). Model Pemberdayaan Santri Ponpes Al- 
Sari, I.N., Juniarsi, F.

Hidayah Batu Alang Sebagai Kader Kesehatan Berbasis Terapi Herbal. Jurnal Inovasi Hasil Pengabdian Masyarakat (JIPEMAS), 1(2), 86-93. https://doi.org/10.33474/jipemas.v1i2.1514

Meihartati, T. (2020). Pentingnya Protokol Kesehatan Keluar Masuk Rumah Saat Pandemi Covid-19 Dilingkungan Masyarakat RT 30 Kelurahan Air Hitam, Samarinda, Kalimantan Timur. Pengabdian Masyarakat, 1(2).

Rahman, A., \& Satria Utama, L. (2020). Kebijakan pemerintah dalam pengendalian covid-19 di provinsi nusa tenggara barat. Jurnal Ilmu Pemerintahan Suara Khatulistiwa, 5(2), 48-71. https://doi.org/10.33701/jipsk.v5i2.1398

Rahmawati, R., Rahmah, S. F., Mahda, D. R., Purwati, T., Utomo, B. S., \& Nasution, A. M. (2021). Edukasi Protokol Kesehatan dalam Menjalankan New Normal di Masa Pandemik Melalui Media Poster. Prosiding Seminar Nasional Pengabdian Masyarakat LPPM UMJ, $1(1)$.

Saputra, N., Fitriyah, F. K., \& Sari, I. N. (n.d.). KESEHATAN FINANSIAL DAN MENTAL: BERDAMPAKKAH TERHADAP PERSONAL RESILIENCE PARA PENDIDIK SEMASA COVID-19?

Sumampouw, O. J. (2020). Pelaksanaan Protokol Kesehatan Corona Virus Disease 2019 Oleh Masyarakat di Kabupaten Minahasa Tenggara. Sam Ratulangi Journal of Public Health, $1(2)$.

WHO. (2020). Modes of transmission of virus causing COVID-19: implications for IPC precaution recommendations. 